Marquette University

e-Publications@Marquette

Marketing Faculty Research and Publications

Marketing, Department of

$10-1-1998$

Reflections on the 1997 Vatican Statements Regarding Ethics in Advertising

Gene R. Laczniak

Marquette University, eugene.laczniak@marquette.edu

Published version. Journal of Public Policy \& Marketing, Vol. 17, No. 2 (Fall 1998): 320-324. Publisher Link. (C) 1998 American Marketing Association. Used with permission. 


\title{
Reflections on the 1997 Vatican Statements Regarding Ethics in Advertising
}

\author{
Gene R. Laczniak
}

I n February 1997, the Vatican Pontifical Council for Social Communications issued a 35-page pamphlet, which provides a religion-based commentary on the ethics of advertising. This document is composed of five sections that endeavor to treat the economic, political, cultural, and moral dimensions of advertising as they affect society. Although the thematic tone of the writing is difficult to capture by excerpting a few paragraphs, the following quotations sample the rhetorical sense of the essay:

On advertising in developing countries: "serious harm can be done them if advertising and commercial pressure becomes so irresponsible that communities seeking to rise from poverty to a reasonable standard of living are persuaded to seek this progress by satisfying wants that have been artificially created" (Section 10).

On the relationship of advertising and the media: "In the competition to attract ever larger audiences and deliver them to advertisers, communicators can find themselves tempted-in fact pressured, subtly and not so subtly - to set aside high artistic and moral standards and lapse into superficiality, tawdriness, and moral squalor" (Section 12).

On the morality of advertising: "Advertising can be tasteful and in conformity with high moral standards, and occasionally even morally uplifting but it can also be vulgar and morally degrading. Frequently it deliberately appeals to such motives as envy, status seeking, and lust. Today, too, some advertisers conscientiously seek to shock and titillate by exploiting content of a morbid, perverse, pornographic nature" (Section 13).

The Vatican essay concludes with the postulation of three ethical principles, which are discussed subsequently. It pointedly calls for greater responsibility on the part of those involved in the advertising industry, especially advertising practitioners. The document states (Section 14),"advertisers-that is, those who commission, prepare or disseminate advertising - are morally responsible for what they seek to move people to do." This pamphlet was distributed in its entirety by the Vatican Office to all Catholic bishops for the purposes of pastoral teaching and reflection. Its explicit target market consists of more than 600 million Catholics worldwide, as well as the global advertising community, but it also is intended for all people of goodwill.

\section{The Statement's Fundamental Structure and Method}

The Vatican essay takes the form of an analytical commentary on the social implications of advertising. The pamphlet, drawing almost exclusively on Catholic religious sources,

Gene R. LACZNiaK is Professor of Marketing, Marquette University. logically moves from a statement of purpose to a final explication of principles. It is composed of four parts and $23 \mathrm{sec}-$ tions and runs approximately 35 pages in length.

The bibliographic citations made throughout the essay are scripturally and religiously rooted. The majority of references are to papal encyclicals and the Catechism of the Catholic Church (1994). These footnoted sources, in turn, are referenced heavily with additional biblical and doctrinal citations and can be used to examine the full scope of religious teaching that is invoked as a basis for the statements made. This approach to source authority can be expected to receive negative comment in most academic circles. That is, many will argue that, to maximize the credibility and defensibility of the observations made in this document, its tenets should be supported not by sectarian, religious documents but mainly by references to the most current and reputable social science and business literature dealing with the social outcomes of advertising. Such criticism partially misses the point.

In the academic world certainly, and in the business environment as well, it should be granted that a religious institution may have something of worth to say about commercial speech as it exists in a complex economic system. In the spirit of open-mindedness, social science academics should welcome diverse opinions on controversial topics. The business community, an entity that explores every nook and cranny of the economic sector in search of new product concepts, also should be accepting of alternative philosophical perspectives. Religious-based commentary offers one such alternative, cultural perspective. This is especially relevant when so many members of the public claim that religious values influence the attitudes they hold. Again, because the citations included in the Vatican paper are religiously rooted, they enable theologians, Christian philosophers, and other interested specialists to track the observations made by the Vatican Office to a more elaborate source authority, grounded in more traditional religious and moral teachings. Yet the amount of scriptural reference contained in the Vatican essay is considerably less than that found in most Papal social encyclicals (i.e., social writings of the Catholic Church). This approach makes the document more accessible to thoughtful laypersons.

In terms of structure, I also find it notable that the commentary premeditatedly uses a carefully crafted rhetoric of refutational, two-sided argumentation. That is, the economic, cultural, moral, and political criticisms of advertising are not made until the corresponding benefits have been postulated and granted fully. Thus, the document explicitly recognizes the potentially controversial nature of advertising while delineating the benefits that it generates. The essay spends four pages articulating the social benefits of advertising. For example, in Section 5, the essay observes: 
"[Advertising] is a necessary part of the functioning of modern market economies which today exist or are emerging in many parts of the world and which-provided they conform to moral standards based upon intricate human development and the common good-currently seem to be 'the most efficient instrument for utilizing resources and effectively responding to the needs' of a socio-economical kind." And, in Section 7, it notes that "advertising itself can contribute to the betterment of society by uplifting and inspiring people and motivating them to act in ways that benefit themselves and others. Advertising can brighten lives simply by being witty, tasteful and entertaining."

Surely such observations, if directed mainly at the advertising community, involve "preaching to the converted." Paying testimony to the benefits of advertising before proceeding to critique it is tactful, but probably not necessary if the primary audience is advertising practitioners. Moreover, when the essay expectedly switches gears to a critique of advertising, most of the laments have been heard and dismissed before (e.g., Levitt 1970). It should be recognized that there is a long tradition of social criticism pertaining to advertising, both outside the institution and within it (Arrington 1982; Calfee and Ringold 1994). For example, as far back as 1907, one social observer wrote, "on the moral side, it [advertising] is thoroughly false and harmful. It breeds vulgarity, hypnotizes the imagination and the will, fosters covetousness, envy, hatred and underhanded competition" (Logan 1907, p. 333). The specific criticisms of advertising that are raised, which will not be belabored in detail here, likewise have been voiced. Cynics in the advertising community dismissively will ask, "So what else is new?" However, another primary audience for the document is the Christian laity, in which case it may be necessary to underscore the usefulness, power, and benefits of advertising before offering some constructive criticism of its social influence.

Again, most of the issues raised regarding the possible economic, political, and cultural harms for which the institution of advertising might be responsible have been dissected previously by serious academic analysis (Rotzoll and Haefner 1990). But elaborate discussion of the questions previously raised by advertising should not imply a consensus resolution of the issues. In the mid-1980s, Richard Pollay authored a now-classic article that examines the everevolving history of advertising criticism as perceived by significant humanities and social science scholars. Pollay (1986, p. 21) writes in summation, "They see advertising as reinforcing materialism, cynicism, irrationality, selfishness, anxiety, social competitiveness, powerlessness and/or the loss of self respect." As such observations suggest, the power and visibility of advertising breeds ongoing, critical commentary in some sectors of society, but often this criticism raises more issues than solutions. For example, one recent literature review, covering the period 1987 to 1993 , found 127 articles published on the topic of advertising ethics alone (Hyman, Tansey, and Clark 1994). That the Catholic Church also might weigh in on this pervasive topic should not be astounding to anyone. Thus, the systematic elaboration of religious values and accompanying citation of supporting writings should be understood as a different and possibly valuable perspective on the impact of advertising in a complex society. For example, Protestant and Jewish academics have drawn on their own religious traditions to offer commentary on addressing and improving business ethics (Camenish 1998; Pava 1998).

\section{The Statement's Likely Impact: Ideal and Actual}

The Vatican pamphlet on advertising ethics will receive a modicum of discussion, especially in Catholic circles, given its source and purpose. For example, I already am aware of several faculty, teaching at Catholic business schools, who have incorporated it into classroom discussions that pertain to the social impact of marketing activities. More than likely, it also will be used by some members of the Catholic clergy as an inspiration for homilies or a possible theme in parish programs or youth education efforts that include social reflections. The Vatican essay also can be expected to fall on some sympathetic ears among nonsectarian audiences, especially those searching for novel ideas wherever they can be found. For example, business academics interested in the questions of public policy and social issues certainly would fall into this category. On the balance, however, I believe this statement will not have much visibility or impact, at least not without a concerted effort to publicize (dare I say advertise?) it to upper-level marketing and advertising executives. According to a New York Times (Charry 1997) article published approximately 30 days after the Vatican essay on advertising ethics had been released, few highprofile advertising practitioners even were aware of its existence. There is little evidence to suggest that awareness levels regarding the content of the document will increase among the advertising community at any time in the future.

Perhaps more disturbing is my contention that, even if the document comes to the attention of the advertising community, the opinions of the Catholic Church on such matters will not be welcomed. On what basis do I say this? Church leaders systematically have opined on other economic issues on previous occasions (Naughton and Laczniak 1993). These observations, directed at the Catholic laity in general, but at the broader business community as well, have not been received graciously by business. For example, in 1986, the U.S. Catholic bishops published a lengthy, thoughtful pastoral letter titled Economic Justice for All (1986). That document attempted to articulate the implications of Catholic social teaching (CST) for the U.S. economy. Specifically, the principles of CST were explicated, and their connections to various managerial issues, such as employment, poverty, and economic development, were laid out comprehensively. In a poll of 2000 randomly selected business executives, reported in Chicago Studies (McMahon 1989), the majority of the executives perceived that this Catholic bishops' letter on economics was a political statement, rather than a constructive contribution to the dialogue regarding social justice. This observation was made despite the majority of executives claiming that religious values significantly influenced their business decision making.

In still another survey of 71 former chief executive officers (CEOs), excerpted in Commonweal (Martin and Laczniak 1988) magazine, the executive respondents were criti- 
cal of many statements in the 1986 Bishops' economic letter. They characterized the marketplace analysis and economic recommendations of the church hierarchy as naïve, socialistic, statist, and bereft of sophisticated economic understanding (Martin and Laczniak 1988).

Perhaps I am overly pessimistic about what the business community reaction to the Vatican statement on advertising will be. But, if it is dismissively negative, as I expect, this is indeed unfortunate. Why? Because the Catholic Church is a prominent religious institution that aspires to function as a moral beacon to enlighten and assist ethics seekers. As such, it ought to speak out on moral questions, including those stemming from the practice of advertising. As the Vatican statement observes at the outset, "In today's society, advertising has a profound impact on people's understanding of life, the world and themselves, especially in regard to their values, and their ways of choosing and behaving. These are matters about which the Church is and must be deeply and sincerely concerned" (Section 1).

As a business professor at a Catholic university, who teaches classes in both competitive strategy and business ethics, I have been asked by corporate executives on several occasions my opinion regarding the standing of the Catholic Church to comment intelligently on economic matters. My standard reply has been to say that Catholic Church leaders probably have at least as much useful to say about "justice" and "fairness" in the operation of the economy as business executives do about the efficient running of universities.

\section{Observations in the Vatican Ethics Statement Likely to Be Attacked}

Almost any assertion pertaining to the social role of advertising has a high likelihood of engendering debate. The Vatican statement on ethics in advertising contains several observations that are likely to serve as lightening rods for controversy. Regrettably, a few of these remarks will bolster the position of those in the business community who contend that the clergy lack economic understanding. For purposes of illustration, I focus on three such postulations from the ethics document.

First, in Section 10, the statement criticizes brand-related advertising for often accentuating irrational buying motives by consumers and causing potentially serious, supposedly ethical, problems. This condemnation is blanket and without sufficient illustration. Presumably, unstated examples, such as targeting $\$ 180$ basketball shoes at the poorest urban youth, would represent such egregious abuse. In these cases, the Vatican and most of us should be outraged appropriately. But, this superficial criticism of branding and brandrelated advertising as often leading to product proliferation and irrational consumer choice is also naïve. Although branding, at the extreme, has been subject to some marketing exploitation, the benefits of branding are well accepted and key elements in enhancing the social value of advertising (Wilkie and Moore-Shay, in press). Even many severe critics of advertising generally are willing to grant this and admit that branding is one of the net "pluses" of complex marketing systems. Branding enables consumers to accrue a shorthand form of product identification and provides them with a longitudinally consistent indicator of price and qual- ity across product categories. My point here is that such hypercritical analysis of possible advertising shortcomings undermines the credibility of the entire Vatican document.

Second, in Section 11, there is an unfortunate foray into the dysfunctions of political advertising. More than likely, this commentary by the Vatican Office was well intended, given that contemporary political campaigns have evolved away from interpersonal communications campaigns to ones that feature mass communications and often contain destructive negative advertising (Laczniak and Caywood 1987). Nevertheless, political advertising, at least in the United States, remains a protected class of speech that arises from constitutional guarantees. For this reason, political advertising would have best been eliminated in the Pontificial discussion. I say this because, by questioning the ethics of political speech, the church raises a frightening specter. If the Vatican is willing to delimit the sacrosanct area of paidfor political debate, advertising executives will wonder how much else church leaders would want to censor quickly. Such issues would have been better addressed in a separate document on the ethics and morality of modern political campaigns.

Third, in Section 14, the Vatican essay raises a dichotomy that, in my opinion, is far too dramatic. Referencing the media in general, and advertising in particular, the essay portrays media practitioners as facing a forked choice: "Either they help human persons to grow in their understanding and practice of what is true and good, or they are destructive forces in conflict with human well-being." Is human nature really so black and white? Does the Vatican believe that all advertising is either all good or all bad? Such simplistic analysis again undermines the credibility of other useful and valuable insights contained in the essay.

\section{Moral Principles Relevant to Improving Advertising Ethics}

The most substantive portion of the document involves the postulation of three principles that should be used to adjudicate the ethics of advertising. According to the Vatican essay, these are the following:

1. A principle of truthfulness. It states that, "advertising may not deliberately seek to deceive, whether it does that by what it says, by what it implies, or what it fails to say" (Section 15).

2. A principle of human dignity. "There is an imperative requirement" that advertising "respect the human person, his right/duty to make a responsible choice, his interior freedom; all these goods would be violated if man's lower inclinations were to be exploited, or his capacity to reflect and decide compromised" (Section 16). In the explication of this principle, promotions that appeal to lust, vanity, envy, and greed are referenced specifically. In addition, advertising that is directed exploitatively at vulnerable groups, such as children, the elderly, and the poor, is mentioned as particularly troubling.

3. A principle of social responsibility. "Advertising that reduces human progress to acquiring material and cultivating a lavish lifestyle expresses a false, destructive vision of the human person harmful to individuals and society alike" (Section 17). Specifically noted in this principle, by way of explanation, are advertisements that encourage lifestyles that contribute to the waste of resources or the despoiling of the natural environment. 
Taken together, the worth of these principles is that they cover important, fundamental, and necessary ground. They remind advertisers of their proactive duties to avoid deception and respect persons, particularly those who are vulnerable, and of the special requirement of enlightened stewardship that managers should embrace in constructing responsible marketing campaigns. The principles serve as noteworthy moral commentary in the long-running debate about how advertising is moderated best from a social and public policy standpoint (e.g., Preston 1994).

However, it is also fair to note that most of the issues addressed by these principles have been brought previously to the attention of the advertising community. The sentiment of nondeception covered in the first principle, at least in its basic form (i.e., "do not intentionally deceive"), is included in most existing professional codes of advertising ethics, as well as in the law. For example, "avoidance of false and misleading advertising" is a specific provision of the American Marketing Association code of ethics (Laczniak and Murphy 1993). And regarding the third ethical principal, advertisers long have espoused a high level of social responsibility. For example, the document titled Standards of Practice of the American Association of Advertising Agencies begins with the following language:

We hold that a responsibility of advertising agencies is to be a constructive force in business. We hold that to discharge this responsibility, advertising agencies must recognize an obligation, not only to their clients, but to the public, the media they employ, and to each other ... unethical competitive practices in the advertising agency business lead to financial waste, dilution of service, diversion of manpower, loss of prestige, and tends to weaken public confidence both in advertisements and in the institution of advertising (quoted in Laczniak and Murphy 1993).

If anything, these three Vatican principles might be faulted as too general. What may be needed more, perhaps, are midrange corollaries that address specific, documentable abuses in the advertising system.

\section{The Professional Responsibilities of Advertising Educators and Practitioners}

In the end, whether cleric, layperson, academic, or advertising practitioner, readers are left with the question: What social obligations are incumbent on advertising executives? Clearly, advertisers have some duties to contribute to the common good. The real debate comes regarding how broadly these social requirement parameters should be drawn and how aggressively practitioners should seek to fulfill their professional duties.

Michael Novak, in his Templeton Prize-winning book, Business as a Calling (1996), addresses the vocation of all corporate managers in a complex world and writes about some of these moral necessities. It is worth remarking that Novak is an economic conservative. He has written eloquently regarding the importance of a free-market system and its inherent connection to political democracy (Novak 1982). Thus, he is highly sympathetic to the economic philosophy of most corporate CEOs.

For the purposes of this article, the most intriguing part of
Novak's (1996) book involves his "seven ethical principles for success." According to Novak, these principles constitute moral imperatives that should be followed by all enlightened, environmentally attuned executives. Some of Novak's principles are straightforward and would be relatively unquestioned by most managers, including obligations to respect the law and communicate regularly with stakeholders. More debatable in their general urgency and economic acceptability, however, would be ethical duties that involve the managerial obligations to create a caring corporate community, work to achieve social justice so that the less fortunate can improve their economic status, and develop a corporate culture that allows managers the freedom to assume voluntary leadership positions that contribute to society.

The common theme of such moral recommendations is that they are extremely proactive in encouraging actions that foster the common good. In effect, Novak's (1996) message, similar to the three principles referenced in the Vatican essay on advertising, underscores a fundamental ethical expectation for managers. These principles remind executives of basic moral duty. That is, many of today's corporate leaders may have forgotten that the basic purpose of the capitalistic system is to allow personal self-interest (i.e., the profit motive) to operate to secure economic efficiency and contribute to the common good. Thus, managers must embrace principles in the routine of their professional lives that motivate them to discharge their social obligations more automatically. The Vatican essay is, first and foremost, an elaborate statement of moral responsibility. It implores advertising professionals always to consider the common good as they engage in their vocational activities.

In today's environment, academics appropriately have increased their scrutiny of advertising practices and the role these play in society. One responsibility of all educators, especially those in marketing and advertising, is to provide students with a proper perspective regarding professional ethics. In other words, it is to guide future managers in developing an ethical conscience as they perfect their decision-making competence. In helping carry out precisely such education, marketing academics in particular, and the advertising establishment in general, should welcome the sort of commentary offered in the Vatican's essay on advertising. Such morally sensitive perspectives should be injected into the ongoing debate regarding what the appropriate and understood social obligations of advertising practitioners should be.

\section{References}

Arrington, Robert L. (1982), "Advertising and Behavior Control," Journal of Business Ethics, 1, 3-12.

Calfee, John E. and Debra J. Ringold (1994), "The 70\% Majority: Enduring Consumer Beliefs About Advertising," Journal of Public Policy \& Marketing, 13 (Fall), 228-38

Camenish, Paul (1998), “A Presbyterian Approach to Business Ethics," in Perspectives in Business Ethics, L.P. Hartman, ed. Chicago: Irwin/McGraw-Hill, 229-38

Catechism of the Catholic Church (1994). Chicago: Loyola University Press.

Charry, Tamer (1997), “Advertising: Roman Catholic Church Gets 
Mixed Review on Ads," New York Times, (March 31), Business Section, 1.

Economic Justice for All: Catholic Social Teaching and the U.S. Economy (1986). Washington, DC: National Conference of Catholic Bishops.

Hyman, Michael Richard, R. Tansey, and Jarvis W. Clark (1994), "Research on Advertising Ethics: Past, Present, and Future," Journal of Advertising, 23, 5-15.

Laczniak, Gene R. and Clarke L. Caywood (1987), “The Case For and Against Televised Political Advertising: Implications for Research and Public Policy," Journal of Public Policy \& Marketing, 6, 16-32.

and Patrick E. Murphy (1993), Ethical Marketing Decisions. Boston, MA: Allyn \& Bacon.

Levitt, Theodore (1970), "The Morality of Advertising," Harvard Business Review, 48, 84-92.

Logan, J.D. (1907), "Social Evolution and Advertising," Canadian Magazine, 28, 333.

Martin, T.R. and Gene R. Laczniak (1988), "Executive Scoreboard: CEOs Respond to the Economic Pastoral," Commonweal, CXV(June 3), 336-38.

McMahon, Thomas F. (1989), "Religion and Business," Chicago Studies, 3-15.
Naughton, Michael and Gene R. Laczniak (1993), "A Theological Context of Work from the Catholic Social Encyclical Tradition," Journal of Business Ethics, 12, 981-94.

Novak, Michael (1982), The Spirit of Democratic Capitalism. New York: Simon \& Schuester.

(1996), Business as a Calling: Work and the Economical Life. New York: The Free Press.

$\rightarrow$ Pava, Moses L. (1998), "Developing a Religiously Grounded Business Ethics: A Jewish Perspective," Business Ethics Quarterly, 8, 65-83.

Pollay, Richard W. (1986), "The Distorted Mirror: Reflections on the Unintended Consequences of Advertising," Journal of Marketing, 50 (April), 18-36.

Pontificial Council for Social Communications (1997), Ethics in Advertising. Vatican City: Vatican Documents

Preston, Ivan L. (1994), The Tangled Web They Weave: Truth, Falsity, and Advertisers. Madison, WI: University of Wisconsin Press.

Rotzoll, Kim and James Haefner (1990), Advertising in Contemporary Society. Cincinnati, OH: Southwestern.

Wilkie, William and Elizabeth S. Moore-Shay (in press), "Marketing's Contributions to Society," Journal of Marketing, forthcoming. 